\title{
"AS MULHERES VOAM COM SEUS MARIDOS": A EXPERIÊNCIA DA DIÁSPORA PALESTINA E AS RELACÕES DE GÊNERO
}

\author{
Denise Fagundes Jardim \\ Universidade Federal do Rio Grande do Sul - Brasil
}

Resumo: Neste artigo, proponho uma reflexão sobre as relações de gênero e as formas de organização da experiência imigratória contemporânea no bojo da experiência diaspórica dos palestinos. Segundo um provérbio árabe, coletado em trabalho de campo, "as mulheres voam com seus maridos". A explicação se refere a um funcionamento peculiar da vida da família árabe que recebe as noras na unidade doméstica do marido, e, por conseguinte, essa unidade é também a do pai do marido. Foi através desse provérbio que tive acesso a um comentário nativo sobre o "ir e vir" de esposas da Palestina ou de outras cidades para residir na cidade do Chuí (RS) e de lá para outras localidades. No mundo pós-colonial, as mulheres se converteram em potentes símbolos de identidade de sociedades e nações. As mulheres islâmicas e, em especial, as palestinas se encontram dentro desse debate ideológico sobre a integridade e autenticidade cultural. Essa fala proverbial nos dá acesso a diferentes pontos de vista sobre os dispositivos culturais que presidem esses fluxos e nos exige uma reflexão sobre as relações de gênero e o modo como analisamos o protagonismo das mulheres muçulmanas.

Palavras-chave: diáspora palestina, família árabe, identidade étnica, mulheres muçulmanas.

\begin{abstract}
This article proposes a reflection about gender relations and the forms of organization of contemporary Palestinian immigrants' experience. According to an Arabian proverb, collected during fieldwork, "the women fly with their husbands". The explanation refers to a kinship structure through which daughters-in-law come to live in the husband's father's domestic unit. This proverb reveals some aspects about the "coming and going" of Palestinian wives who reside or come from other localities to settle in Chui city. In the post-colonial era, women were converted in powerful identity symbols. Islamic women, specially Palestinians women, are part of a ideological debate about cultural integrity and authenticity. That proverb gives us access to different viewpoints on the cultural devices subjacent to those streams and, therefore, demands a reflection on gender relations and ways of analyzing the agency of Moslem.
\end{abstract}

Keywords: Arab family, ethnic identity, Moslem women, Palestinian diaspora. 
Segundo um provérbio árabe, coletado em trabalho de campo no extremo Sul do Brasil, "as mulheres voam com seus maridos”. A explicação se refere a um funcionamento peculiar da vida da família árabe que recebe as noras na unidade doméstica da parentela do noivo. Em termos práticos, cada casamento de uma filha é também um ritual que lembra uma despedida da casa dos pais e uma mudança de cidade. Foi através desse provérbio que tive acesso a um comentário nativo sobre o "ir e vir" de esposas da palestina ou de outras cidades para residir na cidade do Chuí (RS), ou vice-versa.

Tais deslocamentos já tinham sido percebidos em trabalho de campo, não necessariamente vinculado aos casamentos. Inúmeras vezes, minhas visitas às lojas interrompiam ou se sobrepunham às conversas entre mulheres que mostravam fotos de suas viagens de visita a parentes. Entre as mulheres, o tema não era exatamente de fundo "turístico", mas o ato de partilhar informações sobre parentes e comentar os re-encontros. Os homens, por sua parte, junto aos filhos e filhas, me mostravam as fotos da peregrinação a Meca e aos lugares sagrados do islamismo. Didaticamente, me explicavam no que consistia cada passo do ritual da peregrinação, o significado das roupas e objetos trazidos da viagem. Mostravam-me as roupas, suas fotos com as roupas da peregrinação, tapeçarias com a imagem da Caaba expostas na parede de casa, os narguilés expostos na sala e a hamsa dependurada na parede das lojas. Esses eram alguns dos souvenires turísticos das viagens de peregrinação e do re-encontro com parentes residentes na Palestina expostos em suas casas e lojas.

Neste artigo, meu propósito é de evidenciar essa multilocalidade presente nas famílias entrevistadas a partir dos sentidos que a fala proverbial pode evocar sobre as relações de gênero. Enfim, como podemos compreender tal fala em seu contexto de enunciação? Mais do que uma descrição sobre as relações de gênero, o provérbio exige que o coloquemos em seu contexto de enunciação, para compreendermos um pouco mais as dificuldades práticas e afetivas de manter a parentela em deslocamentos internacionais. ${ }^{1}$

O termo "diáspora" foi utilizado por inúmeros trabalhos e embora estejam intrinsecamente relacionados à “diáspora judaica”, outros debates têm evocado a noção de diáspora. Outros ativistas têm se debruçado sobre

\footnotetext{
1 Agradeço a Bela Feldman-Bianco, Carmem Rial e Cristiana Bastos, bem como os demais participantes do simpósio da ABA sobre Circulação Internacional e Transnacionalismo as sugestões e questionamentos que provocaram o formato atual deste artigo.
} 
a experiência dos deslocamentos forçados. ${ }^{2}$ Resulta que uma experiência “transnacional” pode revelar não só os "efeitos” dos deslocamentos forçados, mas as re-elaborações simbólicas que a experiência identitária nos revela e que podem ser extremamente originais ou deveras relacionadas com as noções de continuidade e resistência que o grupo em questão vem re-elaborando sob novos constrangimentos.

Entendo ser extremamente relevante uma aproximação com a experiência imigratória palestina. Essa é uma experiência de desterro e genocídios impetrados sob a rubrica de "guerra", uma definição que, como me lembram colegas, exigiria ao menos dois exércitos. Todavia, os efeitos de uma guerra que atravessa o século $\mathrm{XX}$, e se mantém atual, atinge de modo específico as famílias que buscaram novos caminhos e países.

Resulta importante reconhecer a experiência dos imigrantes de origem palestina, pois nos permite aproximar e entender como um "desterro" acaba sendo re-elaborado a várias vozes. Portanto, observar e conhecer as formas vividas de re-elaboração coletiva do deslocamento forçado implicam não só aproximar-se da imaginação da volta à terra natal ou às origens - em termos amplos -, se trata de dar a conhecer os modos e suas formas de recuperar os laços sociais empreendidos por segmentos sociais contemporâneos. Julgo que através do entendimento dos arranjos matrimoniais e das relações de gênero podemos compreender a confluência entre disposições afetivas e laços sociais presentes nessa experiência imigratória.

Lembro que a literatura sobre "árabes" e "muçulmanos" corre sempre o risco de encontrar-se com uma perspectiva orientalista que sobrepõe experiências diversas do múltiplo "mundo árabe” (um conjunto de países que já experimentou movimentos pan-arabistas, pan-islamistas) como exemplos do “mundo muçulmano". Ora tal perspectiva transforma todo o muçulmano em árabe, como se fossem realmente sinônimos, ora transforma todo sujeito que vive ou se refere à cultura árabe como um muçulmano.

\footnotetext{
2 Ver em Clifford (1997) um importante balanço sobre o uso conceitual do termo “diáspora”. Minha compreensão é de que o autor questiona a rigidez com que o termo pode ser empregado, mostra que o termo evoca uma noção de retorno a uma origem, local ou simbólica, mas que as experiências históricas que conhecemos remetem a experiências de rediasporizações e de uma transfiguração constante das experiências identitárias, paradoxalmente, ao produzir uma "fidelidade” a sentimentos que remetem a uma identidade primordial.
} 
Silva (2008), Hildred Geertz (1979) e Goody (1995), em momentos distintos, nos lembram da imensa dificuldade de produzir totalizações sobre o mundo "oriental" ou islâmico, mesmo que seja através do debate sobre a "família árabe” e as disposições que a pesquisa antropológica extrai do estudo do parentesco. No máximo, as lições sobre família e parentesco encontradas em inúmeros trabalhos propiciam um entendimento inicial sobre a complexidade do debate, entre exigências identificáveis como "princípios genealógicos”, "lealdades geracionais e de gênero" - que não são exclusivas do dito "mundo árabe”, e nos permitem uma compreensão melhor sobre a participação, as lealdades de uma rede de parentes ampliada que interfere na tomada de decisões dos sujeitos. A antropologia sempre primou pelo debate sobre "modelos" de parentesco ressaltando o interesse dos próprios sujeitos de pesquisa quanto ao que fazem com o parentesco e não exatamente perpetuando uma ideia de checar tais modelos ou delineá-los empiricamente pela pesquisa de campo.

Os estudos sobre parentesco e povos de "origem árabe” são vastos, mas também parecem imprecisos quando se busca a definição do que seria uma “família árabe”. Igualmente se referem a uma área vasta do Norte da África que foi historicamente conquistada, e a imprecisão em definir a "família árabe” por parte da literatura não impede que como "valor” não apareça diretamente nas falas de interlocutores em campo.

No caso dos palestinos, sempre tive de evitar a ideia de que o que encontrava em campo traduzia o "mundo muçulmano" atual. Alertada pelos próprios entrevistados, aprendia as inúmeras maneiras de relacionar-se com a religiosidade, e que nem a rubrica "árabe”, nem a rubrica genérica de "muçulmano” me dariam acesso à totalidade das experiências identitárias e geracionais dos imigrantes. O certo seria dizer que, neste artigo, gênero e parentesco nos fornecem não um caminho para desvendar o "mundo muçulmano", mas uma possibilidade de aproximação, nesse caso, da experiência identitária e afetiva com que os imigrantes e seus filhos recorrem ao tema da "tradição" e da continuidade de seu grupo.

\section{Um cenário entre outros da diáspora}

Meu trabalho de campo foi realizado entre os imigrantes de origem árabe, autodenominados palestinos, que vivem no extremo Sul do Brasil, na fronteira 
entre Uruguai e Brasil. Entre os meses de abril de 1996 até 1997 centrei meu trabalho de campo no Chuí e, nos anos posteriores, realizei entrevistas com filhos desses imigrantes residentes em outras cidades do Sul do Brasil. ${ }^{3}$ As observações e entrevistas têm sido realizadas em suas lojas, que são também seu lugar de residência. Retorno periodicamente à cidade e nem sempre consigo encontrar as mesmas pessoas, algumas casas ficam fechadas por longos períodos e, por vezes, algumas famílias passam temporadas fora da localidade.

Os interlocutores de pesquisa que encontro no Sul do Brasil se referem à entrada no Brasil como uma evasão provocada pela criação do Estado de Israel, o que resulta em narrativas sobre as impossibilidades de trabalho e amparo da família para, através da imigração, buscar lugares seguros onde trabalhar e viver. A imigração significava encarar alguns caminhos. Um deles era destituído de um Estado de origem, e assumia-se a condição de refugiado. Até então, ingressar na esfera da ajuda humanitária, como refugiado (na época sem poder ser realocado e somente retornar, o que significava uma renúncia ao estatuto de refugiado) tinha um custo imediato, o de não poder circular entre países através de uma livre escolha. ${ }^{4}$ Era preferível, me dizem, ingressar no Brasil com vistos permanentes concedidos no momento de partida, algo que foi se modificando para outros imigrantes.

De outra parte, a experiência de meus interlocutores revela que seus documentos para sair da Palestina ou eram israelenses (o que não dava acesso ao mundo do trabalho nos países árabes) ou, na melhor das hipóteses, jordanianos. Mais recentemente, alguns filhos obtiveram o passaporte palestino devido a algumas anistias conferidas a estrangeiros ilegais no território palestino.

3 A esse respeito ver Jardim (2001, 2007). Este artigo é uma continuidade das reflexões tecidas em publicação recente e me permitem levar adiante a análise das relações de gênero nesse universo de pesquisa.

4 Torpey (2003) nos chama a atenção para a invenção do passaporte como um processo a ser observado historicamente e que nos revela aspectos do controle da circulação de pessoas, definindo e reduzindo o tempo de permanência e alcance da circulação territorial. Essas formas de controle que se intensificam e internacionalizam nos impuseram uma naturalização de um "direito" de ir e vir, quando, a seu ver, nos fornecem elementos para pensar a sofisticação dos mecanismos estatais de controle de circulação de pessoas, do salvo-conduto como uma carta de um avalista do valor moral do sujeito, para o passaporte. No caso dos palestinos isso é mais drástico, pois a imigração tem de ser inicialmente resolvida e viabilizada apesar da ausência de um passaporte e de um Estado-Nação na orquestra das nações. Portanto, contornar a ausência de um "avalista” (um Estado-Nação) que assegure um lugar de retorno a esse sujeito que pretende imigrar.

Horizontes Antropológicos, Porto Alegre, ano 15, n. 31, p. 189-217, jan./jun. 2009 
Por conta dessas escolhas limitadas é difícil saber quantos são os imigrantes palestinos. Não temos a precisão da burocracia mesmo para os casos de regularização de papéis no Brasil. Para exemplificar, por trás da regularização de papéis de um jordaniano no Brasil pode haver uma história de uma evasão de uma família palestina que seguiu para a Jordânia e depois enviou seu filho para a América. Mais adiante, através de contatos familiares e por casamentos por procuração, a família pode custear a vinda da esposa desse filho, que, por exemplo, pode vir do Kuwait (saindo da guerra, em 1991). ${ }^{5}$ Isso revela a conexidade das carreiras de trabalho no Oriente Médio, e nos aproxima ainda mais da singularidade da experiência recente dos palestinos, referida pelos informantes e por especialistas em imigração palestina como uma diáspora. ${ }^{6}$

Inicialmente, o universo de minha pesquisa contou com a observação de dez famílias, definidas de acordo com seus critérios, o que significa três ou mais unidades domésticas para uma mesma família. No decorrer da pesquisa de campo, encontramos uma referência comum de que os imigrantes mais antigos são provenientes da cidade de Ramallah e arredores. Isso realçava uma origem rural, de vida de povoado. Portanto, durante o campo, o reconhecimento mútuo através da "mesma cidade” se revelava pertinente. Mas as moças que vinham casar e mudavam para o Chuí não eram identificadas pelas mesmas cidades e sim como corresidentes de cidades palestinas onde residiam os parentes. Explicitava-se então uma parentela que dos territórios palestinos, circulando inclusive neles, também havia emigrado para outros países árabes (como o Kuwait, Egito) ou mesmo cidades da Alemanha, Inglaterra e EUA, ou cidades latino-americanas, como Quito ou Buenos Aires.

Mais recentemente, o ir e vir das famílias está sendo atualizado através de informantes-chave: o representante dos imigrantes no clube, a professora

5 As "tramas familiares” e percursos migratórios não são lineares, não só quanto ao percurso até chegar ao Chuí, mas também sobre as nacionalidades diversas obtidas pela família ao longo dessa diáspora. Muitas vezes, a impressão que se tem é que o Chuí, cidade de fronteira entre Brasil e Uruguai, é mais um ponto de passagem (ou parada) para novos deslocamentos do que um destino final. As estimativas que os moradores verbalizam é que a cidade comporte cerca de 200 imigrantes de origem palestina. Entretanto, não há um registro diferenciado para os imigrantes e os filhos nascidos no Brasil. Considerados tanto por moradores brasileiros quanto pelos entrevistados, manejavam sua "origem" diferenciada, paterna ou materna, como a sua autodefinição de "palestinos".

6 A experiência de famílias na diáspora e o atravessamento da experiência da diáspora nas relações familiares é analisada por Feldman-Bianco (1999). 
de árabe na cidade, a inserção no ambiente escolar e a escuta dos professores sobre o que dizem a respeito de seus alunos, além do retorno às casas dos imigrantes da pesquisa original (do final dos anos 1990). Alguns foram recontatados através da ferramenta interativa do Orkut ou por correio eletrônico na internet. Com outros eu simplesmente perdi o contato porque se mudaram de cidade inúmeras vezes.

Em um cenário mais amplo, podemos situar meus interlocutores mais velhos como parte de uma imigração de pós-guerra, relativa à criação do Estado de Israel em 1948. Vendo os mais jovens, notamos que tal evasão já resultara em algum momento da vida familiar no "retorno" como brasileiros estrangeiros na Palestina.

$\mathrm{Na}$ história dos desterros dos palestinos a criação de Israel é um dos episódios fundamentais, vinculados a processos de descolonização e de transpasso de dominação britânica para uma nova repartição do Oriente Médio por potências nacionais estrangeiras. Como mostra Rashid Khalidi (2003), o episódio mais evocado e que explica o termo "palestino", faz referência ao desterro de um local de origem e remete as várias disputas e perdas do controle de seus territórios para Israel. ${ }^{7}$

A experiência dos imigrantes palestinos no Brasil revela os nexos com outras guerras; Guerra dos Seis Dias em 1967, a Intifada em 1987, uma década marcada por guerras civis e perdas de possibilidades de direitos de cidadania (mesmo em Israel ou Jordânia), o que muitas vezes é confundido tão-somente com as impossibilidades históricas de ter reconhecido o Estado palestino.

\footnotetext{
Khalidi (2003) apresenta importantes considerações sobre a identidade palestina e suas reconfigurações diante dos jogos diplomáticos e dos constantes desterros infligidos aos palestinos. Note-se que a categoria de "refugiado" manejada por organismos internacionais não comporta todas as escolhas efetuadas pelos potenciais atingidos pelas guerras de ocupação infligidas por Israel nos territórios palestinos neste século e ao longo do século XX. A opção por passaportes jordanianos, por exemplo, não implica uma renúncia imediata à cidadania palestina, e mesmo a opção por permanecer nos territórios palestinos não exclui a potencialidade de num momento seguinte os sujeitos virem a recorrer à categoria de refugiados, possibilitada pela ajuda internacional. Em outras palavras, como demonstra Morris (1987), os dados quantificados por organismos internacionais, através de categorias manejadas pelo direito humanitário internacional, são também outras arenas políticas, imprecisas e que visam dar a magnitude dos problemas ocasionados nos territórios atingidos por ações bélicas. No meu entendimento, as categorias utilizadas não deveriam reduzir a experiência identitária, mais ampla e densa que as filiações nacionais. Chamo a atenção para essa "soma" de nacionalidades como parte do percurso identitário dos palestinos em diáspora e discordo da busca de uma unicidade da experiência identitária (dos palestinos) buscada prioritariamente através dos registros de nacionalidade. Tais registros são os possíveis, e não necessariamente os desejáveis.
}

Horizontes Antropológicos, Porto Alegre, ano 15, n. 31, p. 189-217, jan./jun. 2009 
Os conflitos armados e fechamento de fronteiras cujo desenrolar observamos nas últimas três décadas permitem entender um constante "ir e vir" de familiares que ora precipitam a emigração, para além dos países árabes, ora têm suas viagens de visitas familiares (de volta) limitadas em virtude da dificuldade de reingresso nos territórios de origem.

\section{Os constrangimentos à circulação internacional dos palestinos}

As experiências transnacionais de imigrantes nos permitem compreender a singularidade da experiência da diáspora dos palestinos. A diáspora palestina nos permite conhecer os novos itinerários e as formas de recriar possibilidades de cidadania "entre" Estados nacionais. Como viabilizam e mantêm tal circulação? Como mantêm a vitalidade de noções de identidade coletiva calcada na evocação de uma origem comum? Tal empreendimento exige dos analistas um olhar mais detido sobre as relações de gênero, sobre o "mercado matrimonial”, e os saberes acumulados pelos imigrantes através de suas relações transnacionais.

Um dos constrangimentos à circulação dos palestinos e que facilita ou impede os deslocamentos da parentela são os passaportes e a dificuldade de uma pessoa, mesmo com nacionalidade brasileira, para transpassar aduanas portando um nome próprio e sobrenomes que evocam uma família árabe. Esses obstáculos exigem um cálculo singular porque criam preocupações ao livre trânsito internacional e, no caso dos filhos de palestinos, empecilhos para a possibilidade de re-encontros entre parentes e "patrícios".

O estudo sobre os palestinos mostra um acúmulo de experiências sobre o ato de transitar entre ordenamentos jurídicos de Estados nacionais diversos. Muitos desses ordenamentos são comuns, por acordos bilaterais e por serem signatários de acordos internacionais, nas formas de acesso a vistos e modalidades (como a reunião familiar). Mas, na prática, são implementados por pessoas de carne e osso, por agentes concretos em países e fronteiras específicas e, portanto, seguem caminhos burocráticos singulares.

Como refere Coutin (2003), o estatuto legal, obtido em um ou mais países de acolhida, pode facilitar a organização da imigração transnacional. Como venho observando entre os imigrantes palestinos e seus filhos, é exatamente através da aquisição de documentos nas sociedades de acolhida que

Horizontes Antropológicos, Porto Alegre, ano 15, n. 31, p. 189-217, jan./jun. 2009 
as possibilidades de trânsito internacional se ampliam. ${ }^{8}$ Alguns sujeitos e famílias estão conseguindo transitar e, inclusive, adquirir uma relativa liberdade de movimentos internacionais, algo a que não teriam acesso se fossem imediatamente classificados como imigrante-pobre, imigrante-problema ou imigrante-ilegal. Isso não se estende a todos, e, como reconhecem alguns de meus entrevistados, é algo que está sujeito a negociação nas aduanas.

Afinal, um nome próprio árabe, um tipo físico, é sempre mais saliente do que a cor e a procedência do passaporte. Sabemos que as classificações associadas ao imigrante são poderosas e limitadoras de um livre trânsito e dos novos destinos que poderiam advir. Além disso, as classificações associam diretamente à imagem física, aos nomes próprios (árabes) dos portadores de documentos, ao estatuto e às acusações morais que vigoram no mercado mundial das documentações e da burocracia de fronteira. ${ }^{9}$

Os palestinos parecem evitar a cidadania de segunda classe, a fragilidade de papéis provisórios e as imagens relacionadas aos despossuídos, imagens atribuídas que os coloquem em uma posição vulnerável em relação aos nacionais ou limitem seu trânsito entre lugares.

Imigrar não é uma tarefa simples. Isso nos permite sublinhar a força de alguns agentes sociais em manejar códigos desvantajosos e direcionar os re-encontros e, em especial, realçar o investimento masculino e feminino no fenômeno imigratório e os modos como esse trânsito internacional é agenciado. Portanto, olhar o que se passa nas famílias e, em especial, nas relações de gênero nos permite compreender a "trama dos afetos" que potencializa e direciona ingressar nas possibilidades jurídicas do reagrupamento familiar.

\section{A família espalhada, uma "experiência em comum"}

A família "espalhada” entre países é algo muito comum entre os imigrantes palestinos e seus filhos. É importante lembrar que faz tão-somente 60 anos

8 Coutin (2003) analisa os rituais de "jurar a bandeira” a que se submetem distintos segmentos de centroamericanos nos EUA. O caminho da nacionalização é pensado como uma possibilidade rápida para escapar das ambiguidades classificatórias e desvantagem social experimentada pelos imigrantes na sociedade de acolhida.

9 Heyman $(1995,2007)$ enfatiza as negociações fronteiriças entre México e EUA. Coloca em relevo os agentes aduaneiros e o modo como interagem com os imigrantes ilegais. 
da proclamação do Estado de Israel. As reiteradas ocupações e redefinições territoriais que se seguiram com as ocupações de territórios palestinos têm produzido um "ir e vir" que por vezes precipita à migração a novos destinos, novos países, e por vezes aponta para períodos, mesmo que breves, de reencontros familiares em território palestino.

Meu trabalho de campo na cidade do Chuí, no final dos anos 1990 até 2000, evidenciava uma série de negociações familiares donde se podia conhecer uma outra face não tão evidente. Todo mapa de parentesco que desenhava junto aos meus interlocutores revelava primos ou tios em países diferentes da América Latina e/ou cidades da Palestina. O mapa era composto de muitos primos conhecidos ou com os quais haviam convivido recentemente, nem todos presentes na cidade do Chuí ou no Brasil.

Chamava-me a atenção essa "presença ausente”. Como sujeitos ausentes tinham tal importância ao longo de suas vidas? Um dos jovens descrevia sua afinidade com a prima que vivia em outro país, no Peru. Citava a prima como uma pessoa com a qual tinha enorme sintonia, segundo ele, quase telepática. Outros revelavam a extrema familiaridade com os primos e tios com os quais conviveram por um período de meses, relatando suas viagens recentes. Aí então apareciam nos mapas de parentesco os parentes ausentes, com enorme intimidade marcada por um convívio breve e que era resultado de re-encontros da parentela propiciados por viagens e convites para morar temporariamente no exterior ou para participar de uma visita para uma festa de casamento. Tais viagens puderam se prolongar para outros países e visitas de outros parentes no hemisfério norte.

Esse "ir e vir" de parentes tinha faces distintas para homens e mulheres, mas traduziam uma enorme cumplicidade geracional entre os jovens, mesmo que sob os cuidados e a tutela de tios e tias.

Nesse cenário de experiências familiares multilocalizadas, destaca-se todo um trabalho de revitalização das relações da parentela que tais viagens propiciavam. Parte desse investimento, ou resultado dessas viagens, se traduzia em possibilidades de encontrar cônjuges, exatamente através das festas de casamento. Lugar por excelência do encontro e da ampliação do mercado matrimonial, ir a uma festa de casamento de antemão já significa um ingresso em uma ampla "vitrine” para os jovens encontrarem outros jovens.

Entre os muçulmanos, me dizem os interlocutores, não existe o namoro. Isso significa na prática inúmeras possibilidades do "namoro escondido", e

Horizontes Antropológicos, Porto Alegre, ano 15, n. 31, p. 189-217, jan./jun. 2009 
exige, novamente, uma cumplicidade geracional (e uma boa dose de risco). Caberia às mães e mulheres casadas da família o papel de intermediárias, conversando sobre o interesse entre jovens para tecer as possibilidades de casar filhos(as) e sobrinhos(as). Assim, além da cumplicidade e interesse geracional por buscar relações entre seus primos, deve-se observar essas outras protagonistas, as mães e tias a quem se delega com confiança a função de encontrar potenciais cônjuges, adequados ao perfil de seus sobrinhos.

Isso nos permite entender como esses "voos" das mulheres são viabilizados nessa trama familiar. Como mostrei em Jardim (2001), embora o relato da imigração seja uma fala autorizada dos homens, em campo percebi uma intensa troca de informações, fotos e possibilidades de re-encontros tecidas pelas mulheres, como mães que procuram cônjuges para filhos e filhas ou como tias que participam dessas redes de casamenteiras, planejando novas viagens e deslocamentos familiares. E filhos que, na ausência de uma "mãe árabe" (imigrante, muçulmana) delegam à irmã do pai a preocupação de estabelecer contatos entre famílias.

Diariamente, são as mulheres - mães e tias - que se ocupam disso e tentam elaborar os possíveis destinos de seus filhos. De modo muito pragmático, são as mulheres que mantêm as trocas de cartas e fotos circulando nas redes de vizinhos no Chuí e entre parentes. Noticiam os nascimentos, a colação de grau nas universidades, discorrem sobre os "frutos" das uniões e, potencialmente, medem as qualidades morais de outras famílias em detalhes cotidianos, nas festas de noivado e casamento de outras famílias imigrantes ou residentes na Palestina - ou em outros países da América Latina. Fotos, cartas e mensagens por fax são os expedientes indispensáveis de uma comunicação nessa rede de mulheres imigrantes.

Nos estudos que versam sobre os imigrantes árabes na América, é difícil saber quando localizamos um "pioneiro". ${ }^{10}$ Atrás de uma história de um imigrante de procedência de país árabe há um contínuo de imigrações que o precederam. Em sua grande maioria, foram imigrações "tramadas" na parentela ou através das relações de vizinhança na aldeia de origem. As mulheres participam da organização da viagem. Penso que elas não estão (apenas) vindo

${ }^{10}$ Ver Truzzi (2007), que analisa a imigração como parte de sistemas imigratórios e nos fornece um balanço sobre os estudos da imigração sírio-libanesa no Brasil. 
depois, estão tecendo as condições da viagem de seus filhos e filhas. Através dos casamentos, o que parece inicialmente ser uma viagem de separação da família de origem pode ser relido como uma nova ligação, uma nova configuração familiar no lugar de destino, um encontro.

Podemos reconhecer, através da experiência mais recente de diáspora palestina, que a viagem adquire outros significados adotando como ponto de vista o protagonismo das mulheres. No caso, são as mães e tias que organizam e atuam em um circuito de comunicação entre familiares: são reconhecidas como mediadoras para traçar casamentos entre jovens, inclusive entre aqueles que vivem em cidades e países distantes. Na aldeia fazem isso normalmente, já que solteiros(as) não se falam diretamente. Contudo, as relações de gênero não se reduzem às relações maritais.

A comunicação é indireta e feita através de inúmeros intermediários que querem “encaminhá-los”. Portanto, elas são mediadoras da comunicação e do interesse recíproco de solteiros e, entre parentelas, colocam no horizonte familiar a possibilidade de casamentos dos jovens. Dessa forma, acabam tecendo novos itinerários e deslocamentos internacionais (e entre cidades) para as mulheres que casam.

\section{Uma história exemplar}

Os acontecimentos recentes da família de Samir nos permitem comentar esse trânsito internacional como parte constitutiva da experiência familiar desses imigrantes e sobre os constrangimentos que permitem e redirecionam o trânsito internacional de palestinos pela América Latina.

Em 2006, Samir acabara de tornar-se reconhecido pelos participantes da sala de oração, que fica no clube árabe-palestino da cidade, como o responsável por chamar os homens para a reza da sexta-feira através de equipamento de som colocado na parte exterior do clube. Ele é formado em engenharia e, embora não se veja como uma pessoa inteiramente preparada para ser chamado de cherk, assume essa responsabilidade como parte de suas obrigações e preocupações com os muçulmanos na localidade.

Ao longo de meu trabalho de campo, nos anos 1990, Samir sempre esteve na cidade e se ausentou do Chuí para cursar engenharia na Palestina, onde conheceu sua atual esposa. Casado e agora com um filho pequeno, Samir 
assume parte das atividades de comerciante empreendidas por seu pai. Todas as suas irmãs puderam estudar e viver na Palestina.

Atualmente, as demais irmãs mais velhas estão casadas e vivem na Palestina. Samir, do contrário, trouxe sua esposa para viver no Chuí. Vive em um confortável apartamento no andar superior da loja do pai. Aliás, como outros comerciantes, o andar superior das lojas pode ter um ou mais apartamentos de moradia para a família, que assim vive junta e de forma "independente".

A esposa Fátima se comunica em árabe e inglês, mas isso não representa um problema, dada a grande quantidade de falantes do árabe na cidade. Sua esposa é habilitada como professora de inglês e dá aulas de árabe para as filhas de imigrantes na sala de trabalho junto a seu apartamento. Conheci Fátima, sua esposa, e nos re-encontramos muito brevemente em algumas ocasiões. Fátima é natural de uma cidade nas proximidades de Nablus. Eles se conheceram lá porque, como relata a esposa, suas famílias se conheciam e as tias fizeram toda a intermediação para que eles viessem a se conhecer. Para vir ao Brasil, ela obteve o visto permanente como brasileira.

Samir reflete sobre as condições de retorno à Palestina para re-encontrar a mãe e irmãs que lá vivem. Para esse filho de imigrante nascido no Brasil é um cálculo que passa por inúmeras variáveis. Relata-me que no tempo que fez sua escolaridade na Palestina vivia com a mãe e suas irmãs e, diferente delas, podia entrar e sair pelo aeroporto de Tel-Aviv porque porta unicamente o passaporte brasileiro. Já fora interpelado na aduana de Israel e perguntado se portava um outro passaporte além do brasileiro. $\mathrm{O}$ fato de não ter passaporte palestino o permitia fazer um caminho mais curto que os demais parentes, ingressar por Israel e não pela Jordânia até sua cidade.

Em 2006, o filho de Samir e Fátima tinha pouco mais de um ano. Samir me diz que o garoto poderá ser anotado na carteira da esposa como filho de palestino. Para uma próxima viagem, para a casa de sua mãe (de Samir), ele deverá acompanhar o trajeto feito pela esposa e filho. Ou seja, deverão entrar na Palestina pela Jordânia e seguir por terra até a fronteira, pois, sendo ela palestina, não poderá descer no aeroporto de Tel-Aviv. Como o filho a acompanhará, mesmo sendo brasileiro, Samir diz que acompanhará os dois nas próximas viagens por esse percurso mais demorado. Lembra que mesmo ela tendo a cidadania brasileira constará também sua cidadania palestina nos registros de aeroporto, e isso a impedirá de aportar pelo aeroporto de TelAviv, devendo chegar através da Jordânia. Se vierem a registrar o menino no 
passaporte palestino da esposa, como quer Samir, calculam que o filho terá a possibilidade de viver na Palestina. Provavelmente, para acompanhar a esposa, nesse hipotético período de residência, ele deverá entrar como turista brasileiro (já que não consta como tendo a cidadania palestina de seu pai). Mas permanecer significa tornar-se um ilegal e esperar uma anistia (de sua situação como ilegal) para a cidadania palestina. Algo que considera muito difícil.

Essa projeção pode ser mais complexa do que resumi. Quero ressaltar que há alguns anos (2000), foi através do depoimento do pai de Samir que ouvi pela primeira vez o provérbio de que "as mulheres voam com seus maridos". Na época, conhecia algo sobre as irmãs de Samir e de que tinham se casado e residiam na Palestina. Hoje em dia, fica mais fácil entender o orgulho de seu Jamal, pai de Samir, ao apresentar-me sua nora e elogiar a sua capacidade de comunicar-se em inglês (é professora formada) e em português. Certamente, ele se referia através do provérbio, na época não exatamente à sua nora (um fato mais recente), mas às demais cinco filhas que estão na Palestina e que lá permaneceram acompanhando seus esposos palestinos. Atualmente, é a nora que veio da Palestina e quem comprova a veracidade do provérbio empregado. ${ }^{11}$ Enfim, ela também fez o seu voo junto ao marido.

Note-se nesse exemplo mais recente que está presente um cálculo sobre a potencial ilegalidade que Samir enfrentaria na Palestina e suas dúvidas quanto à possibilidade de retorno. De outro, a história, além de comprovar "o ponto de vista” de seu Jamal, nos dá elementos para pensar o “voo” de Fátima. É seu Jamal quem me revela que Fátima fora aluna de sua filha nas aulas de inglês e, como refere Fátima, foi através das mães e tias que Samir e Fátima vieram a se conhecer. Em outras palavras, esse "voo" fora viabilizado por inúmeras coincidências e por outros agentes, para além de uma submissão à autoridade paterna, da patrilocalidade ou da realização de uma lógica matrimonial.

Atualmente, o número de alunas da esposa de Samir, Fátima, subiu de cinco (em 2006) para 30, todas meninas, como explica o esposo. Como me lembram Samir e Fátima, ela não poderia dar aulas para homens (garotos acima de dez anos). Em entrevistas feitas em separado todos os dois me explicavam que os meninos aos dez anos estão em uma idade de grandes mudanças

11 Na minha primeira incursão no trabalho de campo, em 1996, havia uma enorme dificuldade de encontrar uma professora de árabe para as jovens filhas de imigrantes.

Horizontes Antropológicos, Porto Alegre, ano 15, n. 31, p. 189-217, jan./jun. 2009 
e passam a ver as mulheres de modo diferente. Também é nessa idade que se deve usar o véu perante essas crianças.

Segundo contam, foram as mães das alunas (residentes no Chuí) que vieram pedir a Fátima para ela dar as aulas de árabe. Comentavam as moças, suas alunas, que outras meninas tinham ido para a Palestina e não se adaptavam muito bem na escola porque não sabiam falar muito bem o árabe. Acabavam ficando para trás nas aulas, ou entrando em turmas que nada tinham a ver com sua idade. As aulas de árabe, como indicavam as meninas, poderiam abrir outras oportunidades, estavam sendo preparadas a uma nova reinserção na vida palestina e para sair do Chuí.

Encontrei suas alunas de árabe na escola estadual. A origem árabe, ou sua “metade” da família árabe, revelava-se de modo pouco elaborado. Citavam seus nomes próprios e ditavam um mapa de parentesco com uma forte ênfase nos laços paternos e maternos e de seus irmãos. Como em outras situações de campo, o aparecimento de primos e tios no Chuí, realizando visitas pontuais, eram parte de um aprendizado sobre a origem palestina e que possibilita inscrevê-los nesses mapas.

Quando conheci o "grupo de meninas” em questão percebi que elas mantinham rotinas compartilhadas. Andavam conjuntamente pela cidade, saíam das lojas no mesmo horário, onde trabalhavam como atendentes, e frequentavam a mesma aula de árabe. As moças não são parentas entre si. Na hora da aula de árabe, por exemplo, saíam das lojas e passavam de loja em loja buscando suas companheiras para caminhar juntas até a casa de Fátima.

Aspectos diversos e constantes dessa solidariedade feminina (e geracional) era algo que também Fátima havia me relatado e que me surpreendera, especialmente seu relato sobre seu pós-parto. Eu a via como uma "recém-chegada”, com um círculo reduzido de pessoas conhecidas. Todavia, ela me relatou aspectos da solidariedade encontrada no Chuí. Todas as mulheres, esposas de imigrantes, vieram visitá-la quando de sua chegada na cidade para saudá-la e desejar-lhe boas-vindas. Contou-me que, quando do nascimento de seu filho, sua sogra voltou da Palestina para ficar com ela. Perguntada sobre como foi o pós-parto e a ajuda que teve, comentou sobre a imensa solidariedade das mulheres no Chuí. Elas entravam em sua casa, faziam café para os visitantes, e sorridente me comenta que ela própria não precisou fazer nada mais do que atender o recém-nascido. 
Como em outras situações de campo, a solidariedade geracional e de gênero aparecem como parte de suas vidas. Desse modo, não é possível entender as negociações familiares e o próprio provérbio restrito à vida marital e às imposições advindas de uma geração a outra. É necessário perceber uma intensa solidariedade e convívio entre mulheres (e entre homens). Ingressamos aí na densidade específica desse provérbio. Enquanto ele nos informa sobre um resultado comum e reitera a patrilocalidade, não nos deixa entrever outros pontos de vista da experiência dos deslocamentos e o modo como são organizados através das relações de gênero.

A "solidariedade feminina" tampouco deveria ser encarada como algo puramente "estrutural" das relações familiares, mas nos ajuda a compreender um pouco mais sobre o debate travado entre a perspectiva colonial feminista e a ótica feminista que vem sendo proposta por Leila Ahmed (1992) e Lila AbuLughod (2002b) sobre as mulheres muçulmanas.

\section{As trocas matrimoniais e seus diferentes pontos de vista}

A fala proverbial de que "as mulheres voam com seus maridos" evoca alguns dos elementos que organizam a imigração e revelam aspectos das relações de gênero. Essa é uma arena dos afetos que nos revela seus custos práticos e afetivos e nos permite inspecionar o comentário à luz das experiências diretas do trabalho de campo sobre as relações de gênero e a imigração, bem como revisitar as interpretações orientalistas que são manejadas sobre as mulheres muçulmanas. ${ }^{12}$

Como mostra Abu-Lughod (2002a), os estudos centrados em um novo feminismo colonialista enfatizam a necessidade de "salvar" as mulheres muçulmanas, e entre as obsessões coloniais desponta o tema do uso do véu como signo da dominação masculina. A crítica orientalista de Abu-Lughod sugere que as situações estudadas (referindo-se diretamente ao Afeganistão), deveriam levar em conta os debates travados na sociedade em questão sobre o mundo feminino como produtos de histórias diferenciadas e de desejos estruturados de modo diferente. Não se trata de um “respeito” puro e simples sobre a lógica

12 Dayan-Herzbrun (1995) menciona a singularidade das mulheres palestinas no mundo árabe como um símbolo da resistência nacional. Parte dessa retórica política que a autora detecta está calcada nos claros sinais evocados pelas mulheres para se diferenciar de outras muçulmanas.

Horizontes Antropológicos, Porto Alegre, ano 15, n. 31, p. 189-217, jan./jun. 2009 
do outro, mas o reconhecimento de uma trajetória de debates sobre igualdade e seus significados simbólicos como produtos de debates históricos.

Lila Abu-Lughod (2002b) recorda os estudos de Leila Ahmed (1992), e o fato de que não é razoável acreditar que os debates sobre emancipação ou escolarização feminina sejam um tema à parte dos debates e da perspectiva feminista de movimentos de mulheres muçulmanas em seus países. Nos lembra que a questão da mulher alimenta contendas ideológicas na atualidade, em especial porque remetem à exigência de que as mulheres ocupem o lugar da autenticidade e sejam símbolos de resistência à influência estrangeira. São as mulheres que acabam despontando como potentes símbolos nacionais, disputadas como sinal da manutenção e da fidelidade às tradições da nação.

Como exemplo, Abu-Lughod (2002b) relembra que há inúmeras controvérsias sobre as mulheres emancipadas e jovens cultas no Egito dos anos 1980. Naquele momento, houve um retorno ao uso do véu. Para a autora, significava um momento em que jovens cultas o utilizavam como um signo de diferenciação entre parentes a fim de exprimir que o mesmo não estaria pondo em risco a sua respeitabilidade. À época as noções de emancipação feminina eram postas lado a lado e como equivalentes à “corrupção ocidental”. Embora nesse cenário de debates recentes as noções modernizantes apareçam vinculadas à condenação dos “casamentos forçados” pelos pais, ao mesmo tempo se multiplicavam as veiculações de outros debates e ideais. Entre eles, o de que os modernos matrimônios deveriam pautar-se pelos valores e ideais do amor romântico e da livre escolha.

As autoras nos mostram que os debates sobre os valores modernos do matrimônio não são alheios às experiências contemporâneas de mulheres e homens nos países árabes. Nos chamam a atenção para um debate que transborda a esfera dos afetos, passando pela veiculação em novelas televisivas, debates de revistas femininas de grande alcance popular e que concorrem com as considerações religiosas re-editando concepções novas e complementares a debates religiosos.

Lembra Abu-Lughod (2002b) que é como se a obrigação religiosa cedesse espaço para um debate sobre a necessidade de que o casal moderno venha a compartilhar valores comuns, entre eles a parceria e a complementariedade do casal, baseado em uma noção (que particularmente se ouve muito entre as mulheres no Chuí) de que é papel da mulher o de "harmonizar” a relação con- 
jugal e familiar. ${ }^{13}$ Portanto, deveríamos extrair algumas lições desse debate. A principal delas diz respeito à necessidade de ampliar nossa compreensão sobre o "alcance" do tema do "matrimônio" pois, quando demasiadamente restrito ao debate sobre "afetos”, não nos deixa entrever os debates sobre valores morais em arenas mais amplas.

Dessa perspectiva crítica, destaco a contribuição de Mervat Hatem (2002) quando analisa a biografia da poetisa A'isha Taymur e nos chama a atenção sobre a necessidade de se descentrar das "narrativas masculinas dominantes". ${ }^{14}$ Essa poetisa consagrada como vanguarda literária no Egito do século XIX é, muitas vezes, vista como o produto de uma família liberal/moderna e identificada com a modernização do Egito e, portanto, como uma agente da mudança. Para Hatem (2002), é necessário prestar mais atenção ao ingresso da poetisa no mundo letrado e deslocar a interpretação das biografias centradas no papel do pai, como aquele que a apoiou a ingressar no mundo literário versus a mãe que representaria a tradição (o mundo das habilidades domésticas) e o desestímulo às letras. De acordo com a autora, as interpretações findam por destacar o poder dos homens e conferem uma atenção secundária às solidariedades entre mulheres (inclusive da própria filha da poetisa) na consagração de A’isha.

As propostas de Mervat Hatem (2002) reiteram a necessidade de se deslocar o ponto de vista para o protagonismo de outros sujeitos ampliando a compreensão das relações de gênero para além da relação marital ou da relação pai-filha. Normalmente, as interpretações sobre a agência das mulheres muçulmanas estão relacionadas às restrições que imputamos à submissão do "outro" e a lógicas presididas por esquemas estruturais da dominação masculina. O provérbio que dá título a este artigo parece sugerir a mesma ênfase. A releitura de Hatem sobre as biografias de A'isha nos sugere a necessidade de analisar outros pontos de vista sobre a experiência de gênero, para além da

${ }^{13}$ Em Jardim (2001) e Jardim e Peters (2005) o ritual do casamento é descrito nas etnografias como uma "costura” de vários elementos: o véu e vestido branco da noiva, o ritual da conversão da noiva e os rituais da hena e da solidariedade das mulheres casadas constituem aspectos de ritual que tem como tema todos esses "pedaços" e citações da tradição. A experiência social revela a tradição revivida pelo grupo e consagrada como parte de um vasto repertório árabe. O relato das noivas e casais valoriza e se utiliza de referências ao ideal de amor romântico. Ver Peters (2006).

${ }^{14}$ A este respeito, ver entrevista de François Héritier (Sztutman; Nascimento, 2004) acerca da leitura de Bourdieu sobre dominação masculina. 
relação masculino-feminino cristalizadas nas relações maritais ou na relação paternal e filial.

Poderíamos realçar o protagonismo feminino no percurso imigratório através dessa fala proverbial? Note-se que ali o protagonismo das mulheres aparece à primeira vista subsumido ou "complementar" àquilo que propõem os maridos.

Permito-me, portanto, retomar o provérbio como uma "pista" explicativa sobre como a parentela tem se mantido em diáspora e como um comentário sobre a perpetuação da migração entre "suas" experiências comuns. Todavia, não poderíamos estender daí que o provérbio traduz tudo sobre as relações de gênero e, ainda mais, tudo sobre as relações maritais e sobre as expectativas entre os sexos.

A sugestão é de que há que se considerar as "situações" e contextos. Tais situações permitem ter acesso a uma trama de relações de gênero mais amplas e diversificadas. ${ }^{15}$ Portanto, estamos falando em termos de disposições, em diversas escalas, que cooperam para a compreensão do provérbio (ou de sua realização) e da própria possibilidade de manter-se a parentela em deslocamento.

No contexto de campo, percebia os acertos matrimoniais não exatamente como um comentário sobre a submissão feminina, mas como algo pensado pelas mulheres (mães e filhas) como parte de um debate delicado sobre possibilidades emancipatórias, ora valorizado como a própria emancipação da filha, ora colocando o matrimônio como parte de um caminho de sucessos femininos que englobaria também o sucesso escolar e a formação acadêmica.

Em geral, o que aparecia em campo, entre mães, e nas conversas entre mulheres, era uma valorização das mulheres através do capital cultural alcançado pela noiva e por sua família. Eram mostradas as joias presenteadas para a noiva, que traduziriam a importância que adquiriria na nova parentela (na família do noivo). Os elementos apresentados materialmente pareciam realçar a relevância da titulação acadêmica da noiva, expressando suas qualidades morais descritas também como habilidades ou "preparo".

${ }^{15}$ Dayan-Herzbrun (1995) nos oferece um debate sobre as imagens da mulher e o nacionalismo palestino. Minhas interlocutoras realçavam a singularidade das palestinas em relação às imagens veiculadas sobre mulheres muçulmanas e submissão feminina. 
No que diz respeito às relações de gênero, tudo é uma questão de ponto de vista, ou melhor, de onde olhamos as negociações matrimoniais; se a partir do grupo feminino, no que se passa entre mães ou entre amigas da noiva. A leitura pode diferir imensamente, sobre a avaliação e o resultado dessa negociação de destinos.

Flanquart (1999) e Belhadj (2000) mencionam a experiência de alta escolarização de mulheres imigrantes argelinas na França. Aquilo que poderia ser apontado como um caminho para a emancipação, através da alta escolarização, pode estar sendo vivenciado como um desafio e tensões entre os projetos familiares e a realização de projetos pessoais. Tal caminho pode significar uma "escolha” pelo celibato. Ou seja, em outros contextos, pode ser um cálculo arriscado. Como nos mostra Belhadj (2000), o investimento em um sucesso escolar não é incompatível com os valores consagrados pela família de origem. Entretanto, sua percepção é de que as escolhas matrimoniais findam por restringir o caminho para uma alta escolarização. Mostra-nos a autora que quem acaba se beneficiando da alta escolaridade de algumas mulheres são suas irmãs mais novas. Essas irmãs poderão usufruir as conquistas (de sua voz ouvida perante a família) e dos novos modelos de traçar a vida familiar negociados com os pais e conquistados pelas irmãs mais velhas.

Em outras palavras, para entender as relações de gênero é importante ter em mente as solidariedades geracionais, sua distribuição diferencial entre mulheres, ou seja, os diferentes pontos de vista dessa negociação de “destinos”. Por conseguinte, o que observamos em um contexto sobre mulheres muçulmanas não necessariamente se repetirá em um outro universo de pesquisa. Parece simples, mas em geral a utilização da literatura acaba aproximando universos de pesquisa e exigindo algum tipo de correlação artificial. Isso não quer dizer que não aprendamos mais sobre as experiências femininas e as solidariedades geracionais e de gênero. Chamo atenção para uma excessiva ênfase na unicidade da experiência de "mulheres muçulmanas" e, em alguns casos, na demonstração da diversidade de "casos" singulares como "matizes do mesmo".

No Sul do Brasil, as viagens poderiam significar uma interrupção abrupta do percurso escolar, posto que compatibilizar sistemas educacionais, validar diplomas ou dar prosseguimento local à escolarização significa ingressar em mais uma arena de validação de papéis. O que está em jogo não são somente vontades individuais, mas a capacidade de poder levar a cabo a continuidade 
da escolarização e demonstrar a compatibilidade entre os projetos familiares e os projetos individuais. Nesse sentido, não se trata de uma incompatibilidade entre o casamento e os estudos, mas avaliações sobre como compatibilizar e resolver dificuldades vislumbradas nos acertos e desacertos desses deslocamentos. Assim como o casamento, as negociações familiares quanto à continuidade da vida escolar apontando para um curso superior dos filhos eram um dos "pontos críticos". O investimento revelava a capacidade da família em custear todos os filhos "nos estudos".

No Chuí, observei algumas moças utilizando como "desculpa” o investimento escolar, valorizado pela família, para protelar o ingresso na "vitrine" matrimonial. Ou seja, protelar a frequência nas festas de casamento no Sul do Brasil: por exemplo, Halila (filha de Subhi) é pressionada pelos irmãos homens, como a filha mais velha, a comparecer a uma festa de casamento a que a família foi convidada. Sua "desculpa” para não ir à festa se apoiava na prioridade do ingresso na faculdade de medicina na cidade vizinha (Rio Grande), lugar em que os pais já mantêm um dos filhos estudando geografia.

Na realidade, as jocosidades dos irmãos explicitam as brincadeiras correntes sobre as "negociações" que são feitas nas festas de casamento, onde grupos de rapazes ficam de um lado e moças de outro. Lembram que se Halila não for estarão excluídos de algumas brincadeiras da festa, em especial, das jocosidades entre os jovens de sua geração. Do lado de lá, dos primos e demais convidados, dizem que não terão uma irmã e, portanto, estarão em desvantagem nesse circuito de jocosidades sobre as "negociações" e trocas de "promessas" que fazem com que as festas sejam tão interessantes. Entretanto, Halila protela seu ingresso através de um argumento importante na vida familiar, a preparação para o vestibular de medicina.

Destaco, assim, as maneiras de manejar e impor vontades nesse jogo familiar de inúmeras vozes. Em outras ocasiões, percebo um enorme empenho de algumas amigas para convencer sua amiga de que a viagem à Palestina poderia ser tão interessante quanto a eleição da sua candidatura como vereadora. As amigas avaliam a escassez de "bons candidatos" no mercado matrimonial conhecido, ou na "mesma faixa etária” da noiva, já que, na avaliação das amigas, a moça esperara demais para casar.

Outras situações revelavam que a família tinha como preocupação não frustrar o investimento profissional e individual realizado por seus filhos. Todas essas preocupações apareciam como decorrentes de experiências de 
conflitualidade já conhecidas na própria família ou de "bons exemplos” comentados na parentela. Ou seja, há que se pensar que determinadas decisões, casamentos, ingresso no mercado matrimonial, escolarização, profissionalização, se tornam “entre imigrantes”, no contexto observado, referências de onde se retiram as experiências modelares para outros filhos de imigrantes:

Sempre eles [os pais] falavam. E aquela coisa também, né, aquele preconceito que... claro, todos nós somos feitos de carne e osso, mas os árabes têm aquele certo preconceito de mulher árabe casar com brasileiro, não pode. De homem brasileiro casar com mulher árabe, não pode. Mas, isso existe um monte. Já na minha família, já, meu pai desde pequenos nos educou que... que... assim, que dentro de nós já tinha isso que... claro, já... como eu vou te dizer, nunca namorei nenhum brasileiro. Sami foi o primeiro, né. Mas, dentro de mim, querendo ou não querendo, sempre teve aquela coisa: vai ser com árabe, vai ser com árabe, entende? Nunca, nunca criei aquela perspectiva de um dia namorar um brasileiro. E desde criança nós fomos educados assim. (Manira).

Essas situações e contexto nos permitem falar em “disposições” culturais e não exatamente em uma cultura muçulmana ou mesmo uma coerência entre o que é vivido no contexto do Chuí com aquilo que as mulheres conheciam na Palestina, ou com o que conhecemos e podemos discorrer sobre "as mulheres muçulmanas”.

Em Jardim (2001), mostrei que no contexto observado duas solidariedades pareciam competir e atravessar as decisões familiares. Uma solidariedade geracional - entre primos - reforçava a voz dos solteiros perante a autoridade da geração mais velha no debate sobre seus destinos. E outra solidariedade entre "tios" (de um outro ponto de vista, trata-se também de uma solidariedade de primos, revitalizada em uma mesma geração - anterior) mostrava-se solidária em acolher as queixas dos sobrinhos e encaminhar moradias temporárias aos mesmos em outras cidades de sua residência. Embora esquemática e quase “estrutural”, a explicação permite compreender essas “forças” que organizam as negociações e tensões familiares. Tais solidariedades se traduzem em grupos masculinos e grupos femininos, que são os interlocutores por excelência das relações nas parentelas, e intermedeiam as decisões, inclusive dos deslocamentos de parentes entre cidades.

O momento de ingressar no circuito de festas ou ser interpelado por escolhas matrimoniais expressa não exatamente um script sobre os modelos de

Horizontes Antropológicos, Porto Alegre, ano 15, n. 31, p. 189-217, jan./jun. 2009 
casamento almejados. Evidenciam sim as dificuldades dos solteiros (no caso de irmãos) em impor a sua vontade frente às inúmeras exigências da parentela (dos pais ou tios). E as preocupações dos pais com os destinos de filhos e, em especial, com a pureza sexual das filhas. Assim, do ponto de vista dos filhos, a vontade de encontrar e re-encontrar seus próprios primos que, por casamento, estão distantes, no Peru, Chile, Venezuela ou Palestina, pode se concretizar por manterem as visitações durante as festas de noivado e casamentos e manter esse circuito como um momento desejado e especial.

Alguns imigrantes projetam os casamentos como a possibilidade de diminuir as distâncias entre primos, falando de um casamento entre seus filhos. É possível dizer que algumas dessas vontades são expressas pelos pais em tom de jocosidade, sobre filhos prometidos. A jocosidade transformara-se em casualidades concretizadas por seus filhos.

No Chuí, pude conhecer um campo de tensões familiares e suas dificuldades em realizar seus casamentos “árabes”. Isso pode se traduzir em um verdadeiro "jogo de empurra” entre irmãos sobre quem deve se casar primeiro e satisfazer as vontades alheias, respondendo às pressões que vêm de algum lado da parentela, e potencialmente rompendo algumas das solidariedades geracionais, especialmente entre irmãos. Exatamente aí, encontramos os primos como os aliados na família, reforçando ou apoiando a participação e sentido lúdico das festas de casamento. ${ }^{16}$ Aparentemente, os rapazes não parecem tão resistentes a apresentarem-se nesse circuito de festas de casamento. Mas não é incomum encontrar filhos homens dos imigrantes que nunca foram a tais festas e que buscaram se descolar desse mercado matrimonial.

Com essas considerações quero realçar que há inúmeros sentidos encobertos pelo provérbio. O provérbio corrobora um "resultado" específico dos casamentos como se eles fossem resultantes de um princípio estrutural (e masculino). De outra parte, há que se ponderar que não se trata de uma simples realização das imposições de uma geração mais velha a outra mais nova. Em especial, a etnografia acrescentou elementos para evidenciar a habilidade das mulheres em organizar tal circulação de noivas, por parte de mães e tias.

${ }^{16}$ Compreender os fluxos de alianças e rivalidades na família como "solidariedades" tidas e vistas como potenciais é uma sugestão que extraio do trabalho de Fonseca (2000). Em Jardim (2001) e no trabalho de Peters (2006) evidenciam-se as dinâmicas das festas de casamento em que jovens homens dançam em grupos e em separado das jovens mulheres. Tal diferença não expressa distâncias e separações entre o masculino e o feminino, e se traduz na performance corporal das festas, as solidariedades entre primos por critério de solidariedade de geração e gênero.

Horizontes Antropológicos, Porto Alegre, ano 15, n. 31, p. 189-217, jan./jun. 2009 
Sugiro que, para pensar esse universo de pesquisa, é necessário ampliarmos o campo de visão e contemplar outros pontos de vista que "jogam" nas relações de gênero. Enfatizo aqui que nas relações de gênero há uma sobreposição entre a solidariedade de geração e de gênero. Isso nos permite compreender um pouco mais sobre outros "pontos de vista" das negociações familiares que concorrem para concretizar os casamentos e potencialmente manter a parentela circulando entre países.

Como lembra Sayad (1977), a verdade da imigração é a ruptura. ${ }^{17}$ Podese afirmar que os imigrantes palestinos atuam no sentido contrário, no esforço por se religar, não exatamente à terra de origem, mas a um amplo repertório de referências culturais e de relações familiares. É difícil saber se isso é próprio dos palestinos ou comum aos imigrantes de primeira geração. Para os palestinos, este novo lugar não se reduz à possibilidade de traçar uma permanência, e sim em um campo de possibilidades e um futuro promissor.

Como vimos, é necessário obter papéis, documentos locais que os situem em um Estado nacional e acumular um capital cultural exigido para viver em outro país, em outro idioma. O horizonte da "volta" tem sido, sobretudo, uma planificação de re-encontros e seus trajetos refletem uma aposta e um risco que deve ser sempre reavaliado.

Entre os obstáculos devemos lembrar sobre a especificidade do nome árabe em um documento internacional e a dupla cidadania como um complicador para esses deslocamentos; por vezes facilita, por vezes reitera a situação de “estrangeiro", nas sociedades de acolhida.

É importante fazer algumas ressalvas quanto a algumas singularidades da imigração palestina. Que singularidades seriam essas? Em especial, deveríamos refletir sobre como ficam esses trânsitos internacionais quando as fronteiras não são tão porosas, quando não é possível negociar sobre um passaporte brasileiro (ou de outro lugar) porque o nome de família árabe é mais poderoso do que os papéis regulares, complicando suas viagens. Outra especificidade é o fato de, mesmo quando existem os papéis individualmente, a vida familiar não é unívoca nos passaportes, seja porque os irmãos podem portar passaportes de diversas localidades por onde já moraram em momentos distintos da

17 No trabalho de Sayad (1977) encontramos diferentes aspectos sobre como a imigração e a ruptura são vivenciadas como experiências geracionais (ressaltando a inserção na sociedade de acolhida) e como experiência partilhada por coletividades.

Horizontes Antropológicos, Porto Alegre, ano 15, n. 31, p. 189-217, jan./jun. 2009 
vida familiar ou porque nem todos os filhos têm a mesma nacionalidade dos pais, ou entre si.

Como demonstrei em Jardim (2001), as mulheres organizam um amplo circuito matrimonial que tem colocado em movimento a circulação de parentes e ampliado as possibilidades do "ir e vir". Elas têm alimentado esse circuito de viagens, que visualizamos como transnacional, mas que identificam como próprio das "famílias espalhadas". Atuam de forma coerente com um modelo conhecido sobre atribuições de gênero tidas como masculinas e femininas.

A imigração palestina tem sido agenciada através de famílias "espalhadas”. Isso tem permitido religar e planejar novos encontros de parentelas através de quadros já conhecidos em sua experiência familiar (de diáspora), trançando encontros e potenciais casamentos. Em outras palavras, tendem a transformar a ruptura em continuidade, sintetizada no provérbio de que as "mulheres voam com seus maridos".

Evidentemente, o termo nativo permite mais de uma discussão, inclusive psicanalítica sobre o termo empregado. Afinal, as mulheres voam quando casadas e estamos tratando ora de destinos, ora de desejos que se entrelaçam com a aquisição desse status da vida adulta.

Creio que o provérbio nos permite conhecer um comentário sobre essa disposição das trocas matrimoniais e pensar sobre como a diáspora palestina é organizada através dos casamentos. De outro, revela um campo mais denso das relações de gênero que não poderiam se reduzir a algo superficial desse comentário, relacionado à vida marital.

Proponho que tais situações demandam pensar no lugar que conferimos à autoridade, cumplicidade e imprevistos na vida familiar, percebendo a dinâmica familiar de modo mais amplo que um simples "ajuste” estrutural das relações de gênero ou restritas às relações maritais.

Sugeri, a partir da Lila Abu-Lughod (2002b) e Hatem (2002), que deveríamos pensar nos diferentes pontos de vista das relações de gênero e suas tensões, contemplando as solidariedades e rivalidades na parentela como instâncias em que se formulam possibilidades e se dão contornos às experiências familiares. É sobre essas situações e contextos que as mulheres muçulmanas organizam sua atuação.

Deve-se ter em mente esse sistema de disposições culturais que viabiliza e disponibiliza os sujeitos a novos deslocamentos. Entre eles, primeiro, o interesse dos jovens em ampliar redes de interconhecimento em sua geração.

Horizontes Antropológicos, Porto Alegre, ano 15, n. 31, p. 189-217, jan./jun. 2009 
Encontrar sujeitos que compartilham dessa mesma "família espalhada”, aliado ao reconhecimento de similitudes como, por exemplo, a autoridade paterna e materna nas escolhas de suas vidas emocionais e profissionais. A solidariedade geracional disponibiliza os jovens a conhecer outros jovens e reconhecer sua experiência familiar na experiência de outros.

Em segundo lugar, o que o provérbio deixa um pouco opaco é o papel das mulheres, como mães e tias, em organizar esses “voos”. A fala é proverbial e revela um comentário nativo que sintetiza uma diversidade de situações de chegada e partida dos parentes. ${ }^{18}$

Em terceiro lugar, que tais disposições são tratadas ora como uma experiência compartilhada, ora como exemplos bem-sucedidos da vida familiar para os imigrantes. Portanto, são disposições amorosas que não se encerram na "vida marital” e que levam sempre em conta os constrangimentos impostos à circulação internacional. Sempre é bom lembrar que portar um nome próprio árabe no passaporte, mesmo um passaporte brasileiro, é limitação bastante conhecida. Mesmo assim, nesse contexto, os imigrantes seguem nominando seus filhos a partir de um estoque de nomes próprios que evocam um repertório tido e visto como árabe. Note-se que isso evidencia um investimento na distintividade e, ao mesmo tempo, na evocação da origem familiar como algo a ser presentificado e a produzir um critério que reduz a disparidade de percepções sobre o sujeito no mundo e seus destinos possíveis.

A imigração não é exatamente uma livre escolha, como lembram os teóricos das motivações econômicas que transformam o ato de imigrar em uma modalidade de solução familiar a uma crise no país de origem. No caso da diáspora palestina, a imigração tem sido eternizada em suas redes, como um destino possível, tanto por questões econômicas e políticas quanto pelo esforço das famílias, e em especial das mulheres, em religar e ressemantizar a experiência da viagem. Portanto, deve-se levar em conta que tais negociações são travadas e pensadas pelos diferentes sujeitos a partir das perspectivas que adotam nas relações de gênero.

${ }^{18}$ Lask (2000) destaca as preocupações de imigrantes brasileiros de origem japonesa residentes no Japão quanto ao domínio de idiomas e credenciamentos escolares em ambos os códigos, japonês e português. Refere a ingerência e preocupação levada a cabo pela geração mais velha em relação aos seus jovens.

Horizontes Antropológicos, Porto Alegre, ano 15, n. 31, p. 189-217, jan./jun. 2009 


\section{Referências}

ABU-LUGHOD, L. Do Muslim Women really need saving? anthropological reflections on cultural relativism and its others. American Anthropologist, v. 104, n. 3, p. 783-790, 2002a.

ABU-LUGHOD, L. El matrimonio del feminismo y el islamismo en Egito: el repudio selectivo como dinámica de la politica cultural postcolonial. In: ABULUGHOD, L. (Org.). Feminismo y modernidad en Oriente Proximo. Madrid: Cátedra, 2002b. p. 355-394.

AHMED, L. Woman and gender in Islam: historical roots of a modern debate. New Haven: Yale University Press, 1992.

BELHADJ, M. Mulheres francesas de origem argelina: conquista de autonomia e reelaboração dos modelos familiares tradicionais. In: PEIXOTO, C. E; SINGLY, F. de; CICCHELLI, V. Família e individualização. Rio de Janeiro: Editora da FGV, 2000. p. 63-78.

COUTIN, S. B. Citizenship, activim and the State: cultural logics of belonging and movement. Transnationalism, naturalization, and U.S. Immigrants politics. American Ethnologist, v. 30, n. 4, p. 508-526, 2003.

DAYAN-HERZBRUN, S. As mulheres e a construção do sentimento nacional Palestino. Cadernos Pagu, n. 4, p. 173-186, 1995.

FELDMAN-BIANCO, B. A família na diáspora e a diáspora na família. In: HOLANDA, H. B. de; CAPELATO, M. H. R (Coord.). Relações de gênero e diversidades culturais nas Américas. Rio de Janeiro: Expressão e Cultura; São Paulo: Edusp, 1999. p. 253-274.

FLANQUART, H. Un désert matrimonial: le célibat des jeunes femmes d’origine maghrébine en France. Terrain, v. 33, p. 127-144, septembre 1999.

FONSECA, C. Aliados e rivais na família. In: FONSECA, C. (Org.). Família, fofoca e honra: etnografia de relações de gênero e violência em grupos populares. Porto Alegre: Ed. da UFRGS, 2000. p. 53-88. 
GEERTZ, H. The meaning of families ties. In: GEERTZ, H et al. Meaning and order in Moroccan society: three essays in cultural analysis. Cambridge: Cambridge University Press, 1979. p. 315-506.

GOODY, J. De ambos os lados do Mediterrâneo. In: GOODY, J. Família e casamento na Europa. Oeiras: Celta, 1995. p. 5-29.

HATEM, Mervat. Las Lágrimas de A’isha Taymur y la crítica de los discursos modernistas y feministas del Egipto del siglo XIX. In: ABU-LUGHOD, L. (Org.). Feminismo y modernidad en Oriente Proximo. Madrid: Cátedra, 2002. p. 113- 133.

HEYMAN, J. McC. Putting power in anthropology of bureaucracy. the Immigration and Naturalization Service at the Mexico-U.S. border. Current Anthropology, v. 36. n. 2, p. 261-287, April 1995.

HEYMAN, J. McC. Grounding immigrant rights movements in the everyday experience of migration. International Migration, v. 45, n. 3, p. 197-202, 2007.

JARDIM, D. F. Palestinos no Extremo Sul do Brasil: identidade étnica e os mecanismos sociais de produção da etnicidade. Chuí/RS. Tese (Doutorado em Antropologia Social)-PPGAS, Museu Nacional/Universidade Federal do Rio de Janeiro, Rio de Janeiro, 2001.

JARDIM, D. F. Estratégias de imigração em tempos da globalização: os palestinos e suas viagens internacionais. In: JARDIM, D. F.(Org.). Cartografias da imigração: interculturalidade e políticas públicas. Porto Alegre: Editora da UFRGS, 2007. p. 245-267.

JARDIM, D. F.; PETERS, R. Os casamentos árabes: a recriação de tradições entre imigrantes palestinos do Sul do Brasil. Revista Anos 90, v. 12. n. 21-22, p. 173-225, jan./dez. 2005.

KHALIDI, R. La construcción de la identidad. La Vanguardia: Dossier Los Palestinos, n. 8, p. 18-21, oct./dic. 2003.

LASK, T. Imigração brasileira no Japão: o mito da volta e a preservação da identidade. Horizontes Antropológicos, ano 6, n. 14, p. 71-92, nov. 2000. 
MORRIS, B. The birth of the Palestinian refugees problem: 1947-1949. London: Cambridge University Press, 1987.

PETERS, R. Imigrantes palestinos, famílias árabes: um estudo antropológico sobre a recriação da tradição a partir da festa e rituais de casamento. Dissertação. (Mestrado em Antropologia Social)-PPGAS, Universidade Federal do Rio Grande do Sul, Porto Alegre, 2006.

SAYAD, A. Les trois “Ages” de l'emigración Algerienne en France. Actes de la Recherche, n. 17, p. 59-79, juin 1977.

SILVA, M. C. da. As mulheres, os outros e as mulheres dos outros: feminismo, academia e Islão. Cadernos Pagu, n. 30, p. 137-159, jan./jun. 2008. Disponível em: <http://www.scielo.br/scielo.php?script=sci_arttext\&pid=S0104-833320 08000100011\&lng=pt\&nrm=iso\&tlng=pt>. Acesso em: 15 jan. 2009.

SZTUTMAN, R.; NASCIMENTO, S. F. Antropologia de corpos e sexos: entrevista com Françoise Héritier. Revista de Antropologia, v. 47, n. 1, p. 235266, 2004.

TORPEY, J. A invenção do passaporte: vigilância, cidadania e o Estado. Lisboa: Actividades Editoriais, 2003.

TRUZZI, O. Rumo a uma compreensão micro-analítica da migração síriolibanesa ao Brasil. In: JARDIM, D. F.; OLIVEIRA, M. A. M de. Os árabes e suas Américas. Corumbá: Editora da UFMS, 2008. p. 145-159. 